African Crop Science Journal by African Crop Science Society is licensed under a Creative Commons Attribution 3.0 Uganda License. Based on a work at www.ajol.info/ and www.bioline.org.br/cs DOI: https://dx.doi.org/10.4314/acsj.v28i3.8

\title{
OCCURRENCE OF COWPEA VIRUSES IN THE FOREST AND SAVANNAH AGRO-ECOLOGICAL ZONES OF GHANA
}

\author{
F.K. ADAMS, L. KUMAR ${ }^{1}$, C. KWOSEH ${ }^{2}$ and R. AKROMAH ${ }^{2}$
}

CSIR-Plant Genetic Resources Research Institute, P. O. Box 7, Bunso, Eastern Region-Ghana

${ }^{1}$ Virology and Molecular Diagnostics Unit, International Institute of Tropical Agriculture (IITA), Ibadan, Nigeria

${ }^{2}$ Department of Crop and Soil Sciences, Faculty of Agriculture, Kwame Nkrumah University of Science and Technology, P.M.B., Kumasi, Ghana

Corresponding author: ffffulera@yahoo.com

(Received 13 December 2019; accepted 28 July 2020)

\begin{abstract}
Cowpea (Vigna unguiculata (L.) Walp) is a major grain legume in Sub Saharan Africa whose production is heavily affected by viral diseases. A disease survey and antigen-coated plate enzyme-linked immunosorbent assay (ACP-ELISA) were used to determine the incidence, severity and occurrence of viruses infecting cowpea in some major growing areas in the Ashanti and Brong Ahafo regions of Ghana. The survey revealed the highest virus incidence (81.6\%) and severity (3.01) in Ejura, and the least incidence (46.7\%) and severity (2.38) in Nkoranza. The ACP-ELISA results indicated that Blackeye cowpea mosaic virus (BICMV) was the most prevalent virus, with occurrence ranging from $32 \%$ in Mampong to $60 \%$ in Atebubu. Cucumber mosaic virus (CMV) was the least detected, occurring only in samples from Nkoranza (4\%). Cowpea mild mottle virus (CPMMV), Cowpea mottle virus (CPMoV), Southern bean mosaic virus (SBMV), Cowpea aphid borne mosaic virus (CABMV) and Cowpea yellow mottle virus (CYMV) were also detected in the samples. The prevalence of these viruses suggest the need for continuous monitoring of cowpea fields in the country to ensure effective disease management.
\end{abstract}

Key Words: Enzyme-linked immunosorbent assay, Vigna unguiculata

\section{RÉSUMÉ}

Le niébé (Vigna unguiculata (L.) Walp) est une légumineuse à grains majeure en Afrique SubSaharienne dont la production est fortement affectée par les maladies virales. Une enquête sur la maladie et un test d'immunosorbant enzymatique sur plaque revêtue d'antigène (ACP-ELISA) ont été utilisés pour déterminer l'incidence, la gravité et la fréquence des virus infectant le niébé dans certaines grandes zones de culture des régions d'Ashanti et de Brong Ahafo au Ghana. L'enquête a révélé l'incidence du virus $(81,6 \%)$ et la gravité $(3,01)$ les plus élevées à Ejura, et la moindre incidence $(46,7 \%)$ et la gravité $(2,38)$ à Nkoranza. Les résultats ACP-ELISA ont indiqué que le virus de la mosaïque du niébé aux yeux 
noirs (BICMV) était le virus le plus répandu, avec une occurrence allant de $32 \%$ à Mampong à $60 \%$ à Atebubu. Le virus de la mosaïque du concombre (CMV) a été le moins détecté, et il ne s'est que présenté dans des échantillons de Nkoranza (4\%). Le virus de la marbrure légère du niébé (CPMMV), le virus de la marbrure du niébé (CPMoV), le virus de la mosaïque du haricot méridional (SBMV), le virus de la mosaïque du puceron du niébé (CABMV) et le virus de la marbrure jaune du niébé (CYMV) ont également été détectés dans les échantillons. La prévalence de ces virus suggère la nécessité d'une surveillance continue des champs de niébé dans le pays pour assurer une gestion efficace de la maladie.

Mots Clés: test d'immunosorbant lié à une enzyme, Vigna unguiculata

\section{INTRODUCTION}

Cowpea (Vigna unguiculata (L.) Walp) is a food legume grown for human consumption in many tropical countries (Singh and Sharma, 1996). It has several importance including high protein content $(25 \%)$, resistance to drought, adaptability to different types of soils and intercropping systems; as well as ability to improve soil fertility (IITA, 2009). According to the Council for Scientific and Industrial Research-Savanna Agricultural Research Institute (CSIR-SARI), Ghana production guide on cowpea, on the basis of area cultivated, the crop is the most important food legume in Ghana. Although the bulk of production occurs in the savannah regions of the north, cowpea is grown in all ecological zones in Ghana. Unfortunately, grain legume yields are often low, mainly due to diseases. Among numerous pathogens are several viruses known to infect the crop to devastating levels (Thottappilly and Rossel, 1992).

Out of about 9 viruses reported on cowpea in Africa (Taiwo and Shoyinka, 1988; Taiwo, 2003), four, namely, Southern bean mosaic virus (SBMV), Cowpea aphid-borne mosaic virus (CABMV), Blackeye cowpea mosaic (BICMV), and Cowpea mild mottle virus (CPMMV) have so far been reported to be infectious to cowpea in Ghana (Zettler and Evans, 1973; Lamptey and Hamilton, 1974; Jeyanandarajah and Brunt, 1993). During the 2015 growing season, viral disease symptoms such as leaf yellowing, mottling, mosaic, green and yellow vein banding, leaf deformation and stunting were observed on cowpea plants in some major growing areas in the Ashanti and Brong Ahafo regions. The objective of the study was to assess the incidence and severity of characteristic virus disease symptoms on cowpea and occurrence of major cowpea viruses in the Ashanti and Brong Ahafo regions, Ghana.

\section{MATERIALS AND METHODS}

Survey methodology. A survey was conducted on 100 cowpea fields, 25 each in Ejura, Mampong, Atebubu and Nkoranza in the Ashanti and Brong Ahafo regions, between November 2015 and March 2016. Twenty-five farms, separated by at least $0.5 \mathrm{Km}$, were randomly selected in each of the four areas and examined for virus symptoms at 5-6 weeks after planting up to flowering. In each field, 30 plants in an ' $\mathrm{X}$ ' transect, with 15 plants per diagonal axis, were visually assessed for the presence of virus symptoms. Viral symptoms such as mosaic, mottling, necrosis, puckering, stunting, deformation and death were scored on a scale of 1-5 (Kumar, 2009), with descriptions as 1 (no visible symptom), 2 (symptoms on $25 \%$ of the plant), 3 (symptoms on $50 \%$ of the plant), 4 (symptoms on entire plant but no stunting or deformation) and 5 (deformation and death of the entire plant).

Percent incidence (Madden and Hughes, 1995) and mean symptom severity (Gumedzoe et al., 1997) were estimated as follows: 
Percent incidence $=$

Number of symptomatic samples x 100 30

Mean severity =

Total score of plants with severity scores $2,3,4$ and 5

Total number of plants with score 2, 34 and 5

In addition, five symptomatic whole leaves were randomly collected from each field. A GPS device was used to measure coordinates and altitudes of the field locations.

ELISA procedure. Antigen-coated plate enzyme-linked immunosorbent assay (ACPELISA), with some modifications, was employed for the detection of the seven viruses in the whole leaves collected from the fields. Antibodies against CABMV, BICMV, CMV, SBMV, CPMoV, CYMV and CPMMV were obtained from the stock of the International Institute for Tropical Agriculture (IITA), Ibadan and used. The leaves were ground in carbonate coating buffer $\left(0.015 \mathrm{M} \mathrm{Na}_{2} \mathrm{CO}_{3}\right.$ and $0.0349 \mathrm{M} \mathrm{NAHCO}_{3}$ ) with DIECA at $100 \mathrm{mg}$ $\mathrm{ml}^{-1}$ buffer $(1: 10 \mathrm{w} / \mathrm{v})$. One hundred microlitres of the extract was added to each well of a microtitre plate. Infected, healthy plant sap and buffer were used as controls. Plates were incubated in a humid chamber for 1 hour at $37^{\circ} \mathrm{C}$, and then washed with three changes of phosphate buffered saline with Tween 20 (PBS-Tween 20), allowing three minutes for each wash. Plates were emptied and tapped dry on a layer of paper towel. Wells were blocked with $200 \mu \mathrm{l}$ of $3 \%$ dried skimmed milk in PBS-Tween 20. Plates were incubated at $37{ }^{\circ} \mathrm{C}$ for 30 minutes, and then tapped dry.

Healthy cowpea leaf extract in PBS-TPO $(1: 10 \mathrm{w} / \mathrm{v})$ was used for cross-adsorption of the antisera at rates as follows: CABMV and BICMV at 1:5000 $\mu \mathrm{l}$; CMV and CYMV at 1:3000 $28 \mu \mathrm{l}$; SBMV, CPMoV and CPMMV at $1: 10000 \mu \mathrm{l}$. One hundred microlitres of the cross-adsorbed antisera was dispensed in each well, and plates were incubated at $37{ }^{\circ} \mathrm{C}$ for 1 hour. Plates were washed and tapped dry as described above. One hundred microlitres of goat anti-rabbit alkaline phosphatase (ALP) conjugate, diluted in conjugate buffer (Ovalbumin, Polyvinyl Pyrrolidone and PBSTween 20) (1: 15,000) was dispensed into each well and incubated for 1 hour at $37^{\circ} \mathrm{C}$. Plates were washed and tapped dry. One hundred microlitres of $0.5 \mathrm{mg} \mathrm{ml}^{-1}$ p-nitro phenyl phosphate substrate in substrate buffer (diethanolamine and distilled water) was added to each well and incubated in a dark room for 1hour.

Absorbance values were measured and plates were kept in a refrigerator at $4{ }^{\circ} \mathrm{C}$ overnight. Quantitative measurements of the p-nitro phenyl substrate conversion resulting in yellow colour were made by determining the absorbance at $405 \mathrm{~nm}$ (A405) in an ELISA plate reader at 1 and 6 hours. The mean absorbance readings of negative controls were determined and twice the values were used as the positive thresholds.

Data analysis. The Statistical Analysis Software (SAS) package (version 9.4, SAS Institute Inc., Cary, NC) was used to analyse the survey data and means were separated using Fischer's LSD at $5 \%$ level of significance.

\section{RESULTS}

Symptoms, incidence and severity. Symptoms observed included leaf mosaic, mottling, necrosis, puckering, plant stunting and death. Ejura (81.6\%) recorded the highest incidence of viral infections; followed by Atebubu (72.5\%), Mampong (70.7\%) and Nkoranza (46.7\%) (Fig. 1). The plants examined in Atebubu, Ejura, Mampong and Nkoranza each had incidences ranging within 83 and 63, 86 and 80, 83 and 63, 56 and 34\%, respectively (Fig. 1). There was no significant difference between Atebubu and Mampong, with few outliers observed in these locations.

Ejura recorded the highest (3.01) mean severity, while Nkoranza recorded the least (2.38) (Fig. 2). Severity scores of Atebubu 


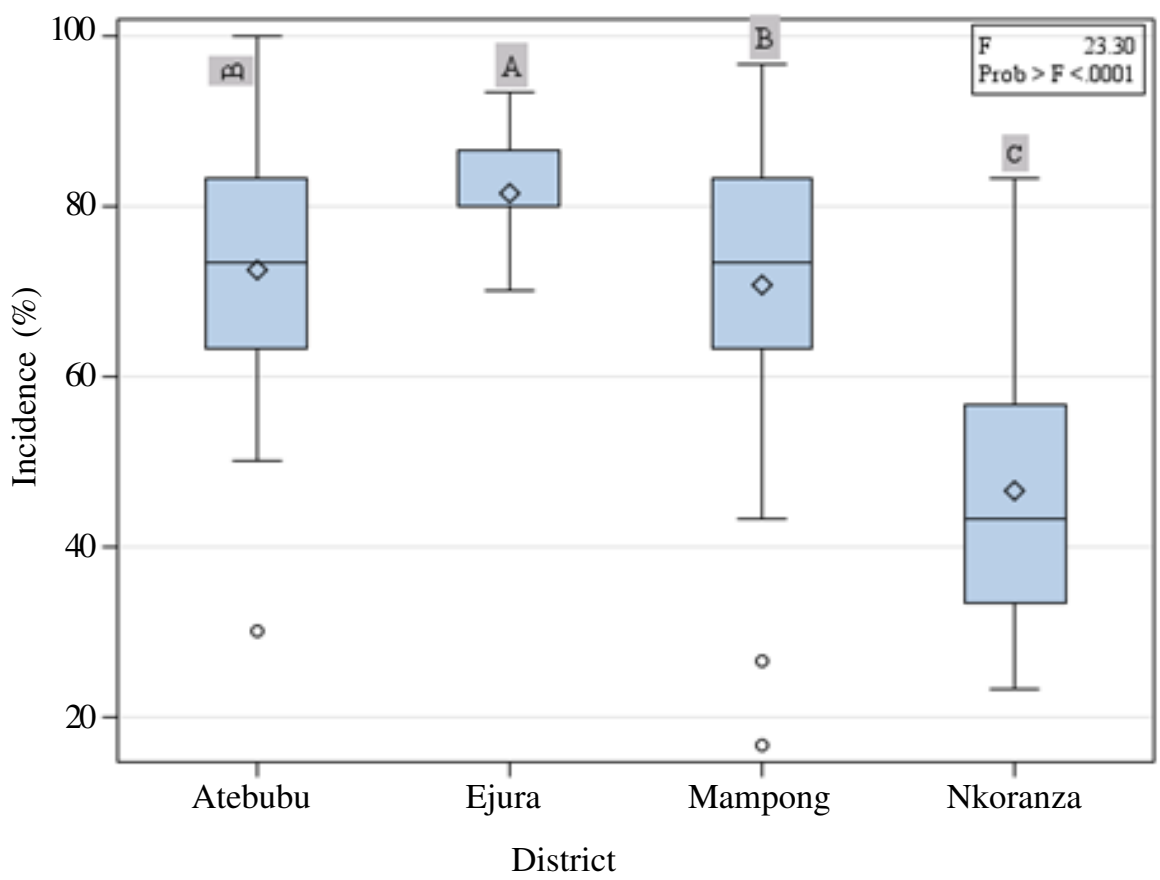

Figure 1. Box plots with whiskers showing the percent incidence of cowpea viral infection observed across four districts in Ghana (Percent incidences of box plots with the same letter on whisker have no significant differences in incidences among them).

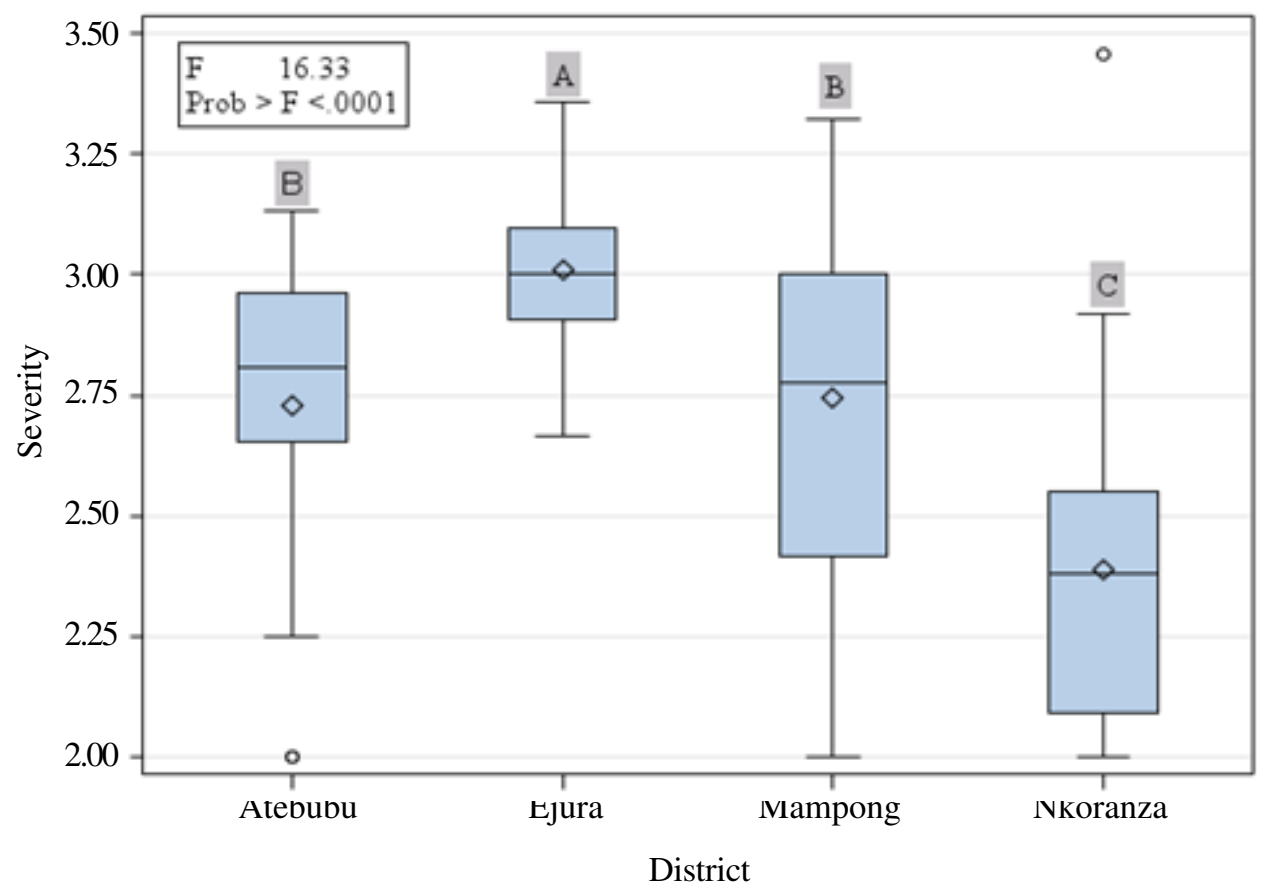

Figure 2. Box plots with Whiskers Showing Mean Severity Indices of cowpea viral symptoms across four districts in Ghana (severity indices of plots with the same letter on whisker have no significant differences in symptom severities among them). 
TABLE 1. Viruses detected in the locations

\begin{tabular}{lccccccc}
\hline District/ Municipal & \multicolumn{7}{c}{ Viruses detected/Percentage occurrence in samples } \\
\cline { 2 - 7 } & CABMV & BICMV & CPMoV & SBMV & CPMMV & CMV & CYMV \\
\hline Atebubu & 4.0 & 60.0 & 48.0 & 8.0 & 60.0 & - & 8.0 \\
Ejura & 4.0 & 52.0 & 16.0 & 4.0 & 28.0 & - & - \\
Mampong & 4.0 & 32.0 & 16.0 & 4.0 & 20.0 & - & 4.0 \\
Nkoranza & - & 40.0 & 40.0 & 4.0 & 32.0 & 4.0 & - \\
\hline
\end{tabular}

$\mathrm{CABMV}=$ Cowpea aphid borne mosaic virus, $\mathrm{BICMV}=$ Blackeye cowpea mosaic virus, $\mathrm{CPMoV}=$ Cowpea mottle virus, SBMV = Southern bean mosaic virus, CPMMV = Cowpea mild mottle virus, $\mathrm{CMV}=$ Cucumber mosaic virus, CYMV = Cowpea yellow mottle virus. (-) denotes absence of virus

and Mampong were 2.72 and 2.74, respectively. The plants examined in Atebubu, Ejura, Mampong and Nkoranza each had symptom severity values ranging within 2.95 and 2.66, 3.16 and 2.19, 3.00 and 2.42, 2.57 and 2.09, respectively (Fig. 2). There was no significant difference between Atebubu and Mampong. Few outliers were observed in the Atebubu and Nkoranza Districts.

Serological detection. The serological results of the occurrence of the viruses in cowpea leaf samples are presented in Table 1. The results indicated that BICMV was the most prevalent virus and occurred in samples from all four locations. The occurrence of BICMV ranged from $32 \%$ in Mampong to $60 \%$ in Atebubu. CPMMV, CPMoV and SBMV were also detected in all four locations with occurrences ranging from $20 \%$ in Mampong to $60 \%$ in Atebubu, $16 \%$ in Ejura and Mampong to $48 \%$ in Atebubu, and $4 \%$ in Ejura, Mampong and Nkoranza to $8 \%$ in Atebubu. CABMV was detected in three locations of Atebubu (4\%), Ejura (4\%) and Mampong (4\%). CYMV was detected in Atebubu (8\%) and Mampong (4\%), while only samples from Nkoranza (4\%) were positive to CMV. Mixed infection of five or more of the viruses occurred in all locations: Atebubu (CABMV + $\mathrm{BICMV}+\mathrm{CPMoV}+\mathrm{SBMV}+\mathrm{CPMMV}+$ CYMV), Ejura (CABMV + BICMV + CPMoV + SBMV + CPMMV), Mampong (CABMV +

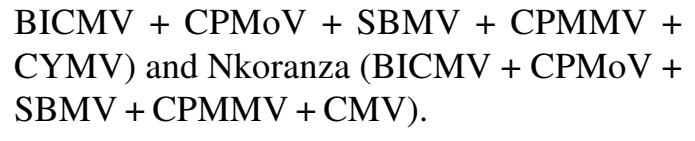

$\mathrm{BICMV}+\mathrm{CPMoV}+\mathrm{SBMV}+\mathrm{CPMMV}+$ CYMV) and Nkoranza (BICMV + CPMoV + SBMV + CPMMV + CMV).

\section{DISCUSSION}

Symptoms of cowpea viral disease. The symptoms observed namely, leaf mosaic, mottling, necrosis, puckering, plant stunting and death are consistent with symptoms previously reported to be associated with infections by CABMV, BICMV, CPMoV, CPMMV and CYMV on cowpea (Amayo et al., 2012; Aliyu et al., 2012). The variation in symptom types may be indicative of multiple viruses infecting cowpea in the surveyed areas. Symptom variation may also be due to factors such as the cowpea cultivars, type of viral strains, time of infection of the pathogen, mixed infections and/or the presence of yet unidentified viruses as reported by Jones et al. (1991).

The result showed that virus incidences and severities were higher in Ejura and least in Nkoranza (Figs. 1 and 2). An observation made in Ejura during the survey was that farmers prefered local cowpea varieties, compared to improved ones. The survey also revealed that farmers in Ejura either kept their own seeds or obtained them from other farmers only within the Ejura district for subsequent sowing. The high incidence and severity of virus infections recorded in Ejura 
may, therefore, be attributed to the highly susceptible local varieties that were preferentially grown by these farmers (Orawu, 2002). Also, since viral symptoms on seeds are not overtly seen, recycling of farmers' own seeds from infected plants for subsequent sowing may have accounted for the high incidence and severity of viral infections observed in the Ejura district. This is in agreement with Booker et al. (2005) who reported that seed transmission provides a very effective means of introducing viruses into a crop at an early stage thus, causing primary infections throughout the planting. The survey data showed that weeds were more abundant in fields in the Ejura district as compared to the other three districts. Mathews and Dodds (2008) reported that most plant viruses had weeds or other alternative natural hosts that provide a reservoir of viruses from which economically important crop plants may become infected. Also, according to Hily et al. (2014), plant viruses require alternate hosts to continue virus-host-vector association, which is crucial for the sustainability of the viral pathogens in the absence of the original crop host. The abundance of weeds and other flora observed in Ejura, as compared to Nkoranza, Atebubu and Mampong may have accounted for the high incidence and severity of viral infections in Ejura.

There were no significant differences in cowpea viral disease incidences and severities recorded in Atebubu and Mampong. Unlike cowpea farmers in the Ejura district, those in the Atebubu and Mampong districts readily exchanged seeds among themselves for subsequent sowing. The similarity in disease incidence and severity between the two districts could be attributed to the initial source of viral inoculum in cowpea seeds exchanged between farmers in the Atebubu and Mampong districts for subsequent sowing (Agrios, 2005).

Nkoranza recorded the least incidence and severity probably because of the proximity of the cowpea fields to each other. It was observed that most cowpea fields in the Ejura, Atebubu and Mampong districts were relatively close to each other. Fields in Nkoranza were relatively farther apart. This could explain why fields in Ejura recorded higher viral disease incidence and severities than Nkoranza, although most farmers in the Nkoranza district kept their seeds for subsequent sowing as well. This is in agreement with findings of Dale (2008) that proximity of fields to each other may cause movement of virus inoculum from an infected to an uninfected field through the vectors, causing relatively high disease incidence throughout the field.

Serological detection of viruses. The ELISA result indicates the occurrence of the seven viruses in the forest and savannah agroecological zones of Ghana, and BICMV as the most prevalent, occurring in samples from all locations. SBMV, CABMV, BICMV and CPMMV were reported previously to be infecting cowpea in Ghana (Zettler and Evans, 1973; Lamptey and Hamilton, 1974; Jeyanandarajah and Brunt, 1993). CPMoV and CYMV are among the viruses severally reported on cowpea in Nigeria (Allen et al., 1982; Aliyu et al., 2012). Also, CMV (Abdullahi et al., 2001) and BICMV (Brunt et al., 1997; Orawu, 2007) were previously reported on infected cowpea plants.

Since initial sources of pathogen inoculum has an effect on disease incidence and severity on fields (Agrios, 2005), high prevalence of BICMV may be attributed to recycling of seeds from season to season by farmers within the study locations. Furthermore, since CMV is readily transmitted by aphids in a nonpersistent manner (Gray, 1996), low occurrence of CMV may be due to farmers' practice of strict calendar spraying to control insect pest including aphids on their fields (Dale, 2008). Mixed infection of five or more of the viruses occurred in all the locations. Shoyinka et al. (1997) opined that the possibility of 3-5 viruses infecting a single plant is not uncommon in nature. The result is also 
in agreement with Aliyu et al. (2012), who reported mixed infections with four viruses; BICMV, CABMV, CPMoV and CYMV on cowpea in Nigeria. Findings similar to this have also been made by Shoyinka et al. (1997) in which mixtures of three viruses; Cowpea severe mosaic virus (CPSMV), CPMMV and CABMV were detected in cowpea plants.

The number of multiple virus infections detected in this study may suggest the presence of virus-complex infections within the study area and possibly within the country. Several reports have shown that multiple virus infections are usually associated with higher disease severity and yield reductions (Taiwo et al., 2006; Kareem et al., 2007). Nondetection of any of the viruses in few samples across the locations may be attributed to low virus concentrations in the leaf samples or presence of serologically variable strains of the viruses or totally different viruses (Aliyu et al., 2012).

\section{CONCLUSION}

This study has revealed that the incidence and severity of the viral infections varies across the study areas, with Ejura recording the highest and Nkoranza the least. BICMV is the most prevalent, and CMV the least detected. CPMoV, CPMMV, CABMV, SBMV and CYMV are also detected in the leaf samples. Single and mixed infections with 5 or 6 viruses are observed. The study suggests the need for continues monitoring of cowpea fields to identify viruses that may be present in other locations in the country to enhance effective cowpea viral disease management and reduction in spread within the country.

\section{ACKNOWLEDGEMENT}

The West African Agriculture Productivity Program (WAAPP-Ghana) funded this study, and the International Institute for Tropical Agriculture (IITA), Ibadan, Nigeria provided logistical support and laboratory facilities.

\section{REFERENCES}

Abdullahi, I., Ikotun, T., Winter S., Thottappilly, G. and Atiri, A. 2001. Investigation on seed transmission of cucumber mosaic virus in cowpea. African Crop Science Journal 9:677-684.

Agrios, G.E. 2005. Plant Pathology ( $5^{\text {th }}$ ed.), Academic press, New York. 952pp.

Aliyu, T.H., Balogun, O.S. and Kumar, L. 2012. Survey of the symptoms and viruses associated with cowpea (Vigna unguiculata (L).) in the agro-ecological zones of Kwara State, Nigeria. Ethiopian Journal of Environmental Studies and Management 5:613-619.

Allen, D.J., Thottappilly, G. and Rossel, H.W.1982. Cowpea mottle virus: Field resistance and seed transmission in virustolerant cowpea. Annals of Applied Biology 100:331-336.

Amayo, R., Arinaitwe, A.B., Mukasa, S.B., Tusiime, G., Kyamanywa, S., Rubaihayo, P.R. and Edema, R. 2012. Prevalence of viruses infecting cowpea in Uganda and their molecular detection. African Journal of Biotechnology 77:14132-14139.

Booker, H.M., Umaharan, P. and McDavid, C.R. 2005. Effect of Cowpea Severe Mosaic Virus on crop growth characteristics and yield of cowpea. Plant Disease 89:515-520.

Brunt, A.A., Crabtree, K., Dallwitz, M.J., Gibbs, A.J., Watson, L. and Zurcher, E.J. 1997. Plant Viruses Online: Descriptions and Lists from the VIDE Database. http:// biology.anu.edu.au/Groups/MES/vide/

Dale, W.T. 2008. Observations on a virus disease of cowpea in Trinidad. Annals of Applied Biology 36:327-333.

Gray, S.M. 1996. Plant virus proteins involved in natural vector transmission. Trends in Microbiology 4:259-264.

Gumedzoe, M.Y.D., Thottappilly, G. and Asselin A. 1997. Occurrence of Southern bean mosaic virus (SBMV) in Togo and its 
interaction with some cowpea cultivars. African Crop Science Journal 5:215-222.

Hily, J.M., Garcý'a, A., Moreno, A., Plaza, M., Wilkinson, M.D., Fereres, A., Fraile, A. and Garcýa-Arenal, F. 2014. The relationship between host lifespan and pathogen reservoir potential: an analysis in the system Arabidopsis thaliana-Cucumber mosaic virus. PLoS Pathog 10:1-13.

International Institute for Tropical Agriculture (IITA). 2009. Available: http://www.iita. org/cowpea. (Last accessed September 2016).

Jeyanandarajah, P. and Brunt, A. 1993. The natural occurrence, transmission, properties and possible affinities of cowpea mild mottle virus. Journal of Phytopathology 137:148-156.

Jones, J.B., Jones, J.P., Stall, R.E. and Zitter, T.A. 1991. Bacterial speck, bacterial spot. In: Compendium of Tomato Diseases. American Phytopathological Society. pp. 26-27.

Kareem, K.T. and Taiwo, M.A. 2007. Interactions of viruses in cowpea: Effects on growth and yield parameters. Virology Journal 4:15.

Kumar, L. 2009. Methods for the diagnosis of Plant Virus diseases, Laboratory Manual. International Institute of Tropical Agriculture (IITA). 94pp.

Lamptey, R.N.L. and Hamilton, R.I. 1974. A new cowpea strain of Southern bean mosaic virus from Ghana. Phytopathology 64:110-114.

Madden, L.V. and Hughes, G. 1995. Plant disease incidence: Distributions, heterogeneity and temporal analysis. Annual Review of Phytopathology 33:529564.

Mathews, D.M. and Dodds, J.A. 2008. First report of Angelonia flower break virus in Nemesia spp. and other ornamental plants in California. Plant Disease 92:651.
Orawu, M. 2002. Occurrence of cowpea diseases and insect pests under different management practices in Eastern Uganda. M Sc. thesis. Makerere University, Kampala Uganda. 85pp.

Orawu, M. 2007. Occurrence of cowpea aphid borne mosaic virus and prospects of improving resistance in local cowpea landscapes in Uganda. PhD thesis. African Centre for Crop Improvement, University of Kwazulu-Natal South Africa. 70pp.

Shoyinka, S.A., Thottappilly, G., Adebayo, G.G. and Anno-Nyako, F.O. 1997. Survey on cowpea virus incidence and distribution in Nigeria. International Journal of Pest Management 43:127-132.

Singh, B.B. and Sharma, B. 1996. Restricting cowpea for higher yield. Indian Journal of Genetics 56:389-405.

Taiwo, M.A. 2003. Viruses infecting legumes in Nigeria: case history. Plant Virology in Sub-Saharan Africa. Hughes, J.A. and Odu, B.O. (Eds.). International Institute of Tropical Agriculture, Ibadan, Nigeria, pp. 365-380.

Taiwo, M.A. and Akinjogunla, O.J. 2006. Quantitative and qualitative effects of single and mixed viral infections. African Journal of Biotechnology 5:1749-1756.

Taiwo, M.A. and Shoyinka, S.A. 1988. Viruses infecting cowpea in Africa with special emphasis on the potyviruses. In: A.O. Williams, A.L. Mbiele, N. Nkouka (Eds). Virus diseases of plants in Africa, OAU/ STRC Scientific publications, Lagos, Nigeria. pp. 93-115.

Thottappilly, G. and Rossel, H.W. 1992. Virus diseases of cowpea in Africa. Tropical Pest Management 38:337-348.

Zettler, F.W. and Evans, I.R. 1973. Blackeye cowpea mosaic virus in Florida. Host range and incidence in certified cowpea seeds. Proceedings of Florida State Horticultural Society 85:95-101. 